\title{
In Silico Pharmacokinetics Studies for Quinazolines Proposed as EGFR Inhibitors
}

\author{
Gabriela Souza Fernandes ${ }^{1}$, Michelle Bueno de Moura Pereira ${ }^{1}$, \\ Ana Cláudia Barbosa Marinho', Brisa Machado², Ana Carla Moreira ${ }^{2}$, \\ Matheus Puggina de Freitas ${ }^{3}$, Karen Luise Lang ${ }^{2}$, João Eustáquio Antunes ${ }^{2 *}$ \\ ${ }^{1}$ Department of Medicine, Federal University of Juiz de Fora, Governador Valadares, Brazil \\ ${ }^{2}$ Department of Pharmacy, Federal University of Juiz de Fora, Governador Valadares, Brazil \\ ${ }^{3}$ Department of Chemistry, Federal University of Lavras, Lavras, Brazil \\ Email: *joao.antunes@ufjf.edu.br
}

Received 20 November 2015; accepted 21 December 2015; published 25 December 2015

Copyright (C) 2015 by authors and Scientific Research Publishing Inc.

This work is licensed under the Creative Commons Attribution International License (CC BY). http://creativecommons.org/licenses/by/4.0/

(c) (i) Open Access

\begin{abstract}
In silico pharmacokinetics studies can aid the search for molecules with potential ability to be drug candidates. In this paper, a number of quinazoline candidates for epidermal growth factor receptor inhibitors-EGFR, important targets for the treatment of cancer, are computationally analyzed. The literature described that 69 quinazoline molecules were synthesized and the respective half maximum inhibitory concentrations $\left(I C_{50}\right)$ were obtained. A bilinear parabolic model was built to investigate the druglikeness by correlating the corresponding lipophilicities, which can be represented by the ideal $\log P$, with the optimal biological activity in terms of $p C_{50}$ values. Structural characteristics leading to improved pharmacokinetics parameters were then analyzed. Compound 56 exhibited the lowest $I C_{50}$ and, therefore, it had the highest ability to inhibit the EGFR. In the present work, the most potent inhibitor 56 is not calculated to be the most promising drug candidate, since it's out of the parabolic model obtained due to a $\log P$ above 5 , which is not within the expected optimum range. Finally, this work is an example of computational prediction that an experimentally, highly active EGFR inhibitor can be unsuccessful as drug candidate because of pitfalls in pharmacokinetics parameters.
\end{abstract}

\section{Keywords}

Cancer Treatment, Quinazoline, Inhibitors, Rational Drug Design, Pharmacokinetics

\section{Introduction}

The action of a drug depends initially on the reach of a specific active site in a sufficient concentration and for a

\footnotetext{
*Corresponding author.
}

How to cite this paper: Fernandes, G.S., de Moura Pereira, M.B., Marinho, A.C.B., Machado, B., Moreira, A.C., de Freitas, M.P., Lang, K.L. and Antunes, J.E. (2015) In Silico Pharmacokinetics Studies for Quinazolines Proposed as EGFR Inhibitors. Open Journal of Medicinal Chemistry, 5, 106-115. http://dx.doi.org/10.4236/ojmc.2015.54007 
sufficient period of time to the occurrence of a pharmacological response [1]. Pharmacokinetic is the study of the relationship between drug response and $A D M E$ factors, i.e. absorption, distribution, metabolism and ex-cretion [1]. In this context, the physicochemical properties of certain functional groups are crucial keys to the pharmacodynamic action of drugs and molecular recognition since the affinity of a drug for its receptor is dependent on the interaction between pharmacophoric groups and the complementary sites of the macromolecule [2]. Additionally, the pharmacokinetic and bioavailability affect directly the drug half-life time and can also be dramatically affected by varying the physicochemical properties of a drug. The main physicochemical property of a molecule capable of changing its pharmacotherapeutic profile is the partition coefficient, which expresses the relative lipophilicity of the molecule, and the ionization coefficient, expressed by $p K a$, which reflects the relative contribution of neutral and ionized species [2].

The lipophilicity $(\log P)$ is defined as the partition coefficient of a substance between an aqueous and an organic phase. The currently accepted concept for partition coefficient $(P)$ can be defined as the ratio between the concentration of the substance in the organic phase $(C \mathrm{org})$ and its concentration in the aqueous phase $(\mathrm{C} a q)$ in a two compartment system under equilibrium conditions. Drugs that have a higher partition coefficient, i.e., those possessing a higher affinity for the organic phase, tend to overcome more easily the hydrophobic membranes [3]. The logarithm of the partition coefficient $(\log P)$ is usually correlated with biological activity, according to a bilinear parabolic model [4]. This model indicates that there is optimal lipophilicity, which can reflect pharmacokinetic and pharmacodynamic requirements, whose increase leads to a progressive reduc- tion of the biological activity [3].

In this context, Lipinski et al. [5] have contributed to the development of new drugs in terms of computational and experimental approaches to estimate solubility and permeability of new drug candidates. According to Lipinski et al. [5], the rule five predicted for a candidate molecule that presents poor absorption and permeability should present the following parameters: $\log P>5$, molecular weight $(\mathrm{MM})>500$, Hydrogen $(\mathrm{H})$ bond donor number $>5$, and number of acceptors $\mathrm{H}$ bond $>10$. The computational methodology for this log-based rule is well described and, after this immense contribution, several similar methodologies have been developed and allowed the development of various programs for the prediction of new drug candidates, including $A D M E$ parameters. Platforms such as Cheminformatics Molinspiration [6] and ICM-Molsoft [7] allowed the user to perform calculations of the Lipinski's rule of five to contribute to the development of new drug candidates through in silico pharmacokinetics studies.

\subsection{Quinazolines}

The chemistry of heterocyclic compounds comprises at least half of all researches in the field of organic chemistry and forms the basis of many pharmaceutical industries, veterinary products and agrochemicals [8]. In the last decade, as a result of a wide range of applications of heterocycles in the pharmaceutical and medicinal chemistry, the synthesis of these compounds has become a big target in synthetic organic chemistry [9].

In recent years, with major advances in the synthesis of heterocyclic structures, the literature contains more than one class of biologically active compounds [10]. Among them, the nitrogenous heterocyclic 4-(3H)-quinazolinones and substituted quinazolines represent a very important class of drugs with several biological properties, such as anticancer [11], diuretic [12], anti-inflammatory [13], anti-convulsant [14] and anti-hypertensive [15] activities.

The interest in the medicinal chemistry of quinazolinones derivatives was stimulated in the early 1950s with the elucidation of the structure of Febrifugina [16], an alkaloid, which was effective against malaria. The methaqualone [17] was first synthesized in 1951 and is the best known quinazolinone derivative, famous for its hypnotic-sedative effects [18]. From these data, there has been a growing scientific interest in the fields of isolation, synthesis and pharmacological properties of compounds related to quinazolinones [18].

Like quinazolinones, the quinoline pharmacophoric group is widely recognized in organic synthesis and can be found in a wide variety of compounds, such as 4-anilinoquinazoline derivatives with known biological properties. These compounds are reported in the literature as potent and selective inhibitors of tyrosine kinase pertaining to the epidermal growth factor (EGF) family of receptors [19]. In addition, knowledge of these enzymes inhibition process appears to be the path for the therapy of many diseases, such as cancer, "psoriasis" as diabetes, cardiovascular diseases, among others [20]. From this evidence, there have been more detailed studies on the biological function of a number of derivatives of this structural class [21]. 
Numerous studies of structure-activity relationships (SAR) involving many series of quinazoline derivatives have led to advances in power, specificity and the pharmacokinetics properties of these inhibitors [22]. For instance, three drugs, Gefitnib (Iressa) [23], Erlotinib (Tarceva) [24] and Lapatinib (Tykerb) [25] have been approved by the FDA and have been marketed for the treatment of lung cancer cells. In addition, several reversible and irreversible inhibitors of epidermal growth factor receptor inhibitors (EGFR) tyrosine kinase are currently being investigated [12] [26]. These small molecules mimic region of the ATP adenine and therefore are potent competitive inhibitors of ATP [27].

\subsection{EGFR Inhibitors and Cancer}

Many of the tyrosine kinase enzymes which are early components of the growth signal transduction pathway in mammalian cells are encoded by proto-oncogenes, and their transformation or overexpression has been shown to occur in a large percentage of clinical cancers. These tyrosine kinase enzymes, especially the receptors for growth factors, such as EGF and platelet-derived growth factor (PDGF), have thus become important targets for drug design [11]. Previous evidence has shown the importance of correlating the pharmacokinetics parameters with the drug's effectiveness. This study has the objective of investigating whether experimentally available quinazolines as EGFR inhibitors have good in silico pharmacokinetics parameters. A particular importance of this study is to reinforce that not always the most potent inhibitor is the one that presents the best phar-macokinetics parameters and, therefore, is the most promising drug candidate.

\section{Results and Discussion}

\subsection{Analysis of Pharmacokinetic Profile for a Number of Quinazolines}

Table 1 shows 69 quinazoline molecules studied to assess the in silico pharmacokinetics profiles. According to the calculations performed to obtain the parameters of the Lipinski's rule of five, molecules 56, 57, 58, $\mathbf{6 8}$ and 69 violated the rule about $\log P(>5)$. However, according to calculations, other molecules are prone to exhibit good oral bioavailability.

A drug should have good pharmacokinetics parameters, being absorbed acting as a potent inhibitor. The absorption includes the transference of the drug into the bloodstream [28]. In the past, many scientific studies in drug discovery were based on the synthesis of inhibitors and inhibition using in vitro tests to choose the best molecules and continuing the drug development. Such a methodology does not take into account the phar-macokinetics properties of molecules and, therefore, many potent inhibitors were discovered, but not approved as drugs [28]. The modern methodology in drug development allows the rational design of new drug candidates by screening not only potent inhibitors, but also molecules with improved pharmacokinetics properties [28]. This work is intended to apply such an approach to develop potential drug candidates with lower risk to fail.

This work was based on 69 quinazoline compounds synthesized by Bridges [11], whose ability to inhibit EGFR was described by $I C_{50}$. In that study, the most active compound was named $\mathbf{5 6}$ and then considered as the most promising EGFR inhibitor. Further studies for the development of EGFR inhibitors were then inspired on molecule 56. The present work demonstrates that compound 56, as well as 57, 58, 68 and 69 molecules, violated a key parameter of the Lipinski's rule of five, the $\log P$, thus rising the chance of having problems with oral bioavailability [5], i.e. the dose of the drug fraction that is found in the general circulation [29]. Preliminary computational studies can support the selection of compounds with prospective good bioavailability performance from a pool of molecules [28]. Molecules violating the rule for $\log P$ can be checked in Table 1; consequently, these molecules may have poor absorption when administered orally.

\subsection{Analysis of Pharmacokinetic Profile of the Drugs Using the Drug-Likeness Score}

Figure 1 demonstrates that molecule 56, which has the best experimental bioactivity, is not expected to show acceptable pharmacokinetic profile, such as low oral bioavailability, according to the low drug-likeness score obtained from the calculations using Molsoft [7].

\subsection{Selection of Molecules to Create the Bilinear Model to Make the Correlation between Biological Activity and Lipophilicity}

Figure 2 shows a series of molecules with $\log P$ and $p I C_{50}$ values within an optimal range, i.e. molecules that 
<smiles>[R]c1cccc(Nc2ncnc3cc([Y5])c([R])cc23)c1</smiles>

\begin{tabular}{|c|c|c|c|c|c|c|c|}
\hline No. & $\mathbf{R}_{\mathbf{1}}$ & $\mathbf{R}_{\mathbf{2}}$ & $\mathbf{X}$ & Formule & $\mathrm{IC}_{50}{ }^{\mathrm{a}}(\mathrm{nM})$ & $\log P$ & $\mathbf{N}^{0}$ violation \\
\hline 1 & $\mathrm{H}$ & $\mathrm{H}$ & $\mathrm{H}$ & $\mathrm{C}_{14} \mathrm{H}_{11} \mathrm{~N}_{3}$ & 344 & 3.14 & 0 \\
\hline 2 & $\mathrm{H}$ & $\mathrm{H}$ & $\mathrm{F}$ & $\mathrm{C}_{14} \mathrm{H}_{10} \mathrm{FN}_{3}$ & 56 & 3.62 & 0 \\
\hline 3 & $\mathrm{H}$ & $\mathrm{H}$ & $\mathrm{Cl}$ & $\mathrm{C}_{14} \mathrm{H}_{10} \mathrm{ClN}_{3}$ & 23 & 4.03 & 0 \\
\hline 4 & $\mathrm{H}$ & $\mathrm{H}$ & $\mathrm{Br}$ & $\mathrm{C}_{14} \mathrm{H}_{10} \mathrm{BrN}_{3}$ & 27 & 4.34 & 0 \\
\hline 5 & $\mathrm{H}$ & $\mathrm{H}$ & I & $\mathrm{C}_{14} \mathrm{H}_{10} \mathrm{IN}_{3}$ & 80 & 4.60 & 0 \\
\hline 6 & $\mathrm{H}$ & $\mathrm{H}$ & $\mathrm{CF}_{3}$ & $\mathrm{C}_{15} \mathrm{H}_{10} \mathrm{~F}_{3} \mathrm{~N}_{3}$ & 577 & 4.35 & 0 \\
\hline 7 & OMe & $\mathrm{H}$ & $\mathrm{H}$ & $\mathrm{C}_{15} \mathrm{H}_{13} \mathrm{~N}_{3} \mathrm{O}$ & 55 & 3.05 & 0 \\
\hline 8 & $\mathrm{OMe}$ & $\mathrm{H}$ & $\mathrm{H}$ & $\mathrm{C}_{15} \mathrm{H}_{12} \mathrm{BrN}_{3} \mathrm{O}$ & 30 & 4.26 & 0 \\
\hline 9 & $\mathrm{NH}_{2}$ & $\mathrm{H}$ & $\mathrm{H}$ & $\mathrm{C}_{14} \mathrm{H}_{12} \mathrm{~N}_{4}$ & 770 & 1.86 & 0 \\
\hline 10 & $\mathrm{NH}_{2}$ & $\mathrm{H}$ & $\mathrm{CF}_{3}$ & $\mathrm{C}_{15} \mathrm{H}_{11} \mathrm{~F}_{3} \mathrm{~N}_{4}$ & 574 & 3.07 & 0 \\
\hline 11 & $\mathrm{NH}_{2}$ & $\mathrm{H}$ & $\mathrm{Br}$ & $\mathrm{C}_{14} \mathrm{H}_{11} \mathrm{BrN}_{4}$ & 0.78 & 3.06 & 0 \\
\hline 12 & $\mathrm{NO}_{2}$ & $\mathrm{H}$ & $\mathrm{H}$ & $\mathrm{C}_{14} \mathrm{H}_{10} \mathrm{~N}_{4} \mathrm{O}_{213}$ & 5000 & 2.87 & 0 \\
\hline 13 & $\mathrm{NO}_{2}$ & $\mathrm{H}$ & $\mathrm{Br}$ & $\mathrm{C}_{14} \mathrm{H}_{9} \mathrm{BrN}_{4} \mathrm{O}_{2}$ & 900 & 4.07 & 0 \\
\hline 14 & $\mathrm{NO}_{2}$ & $\mathrm{H}$ & $\mathrm{CF}_{3}$ & $\mathrm{C}_{15} \mathrm{H}_{9} \mathrm{~F}_{3} \mathrm{~N}_{4} \mathrm{O}_{2}$ & $>10^{4}$ & 4.08 & 0 \\
\hline 15 & $\mathrm{H}$ & $\mathrm{MeO}$ & $\mathrm{H}$ & $\mathrm{C}_{15} \mathrm{H}_{13} \mathrm{~N}_{3} \mathrm{O}$ & 120 & 3.05 & 0 \\
\hline 16 & $\mathrm{H}$ & $\mathrm{MeO}$ & $\mathrm{Br}$ & $\mathrm{C}_{15} \mathrm{H}_{12} \mathrm{BrN}_{3} \mathrm{O}$ & 10 & 4.26 & 0 \\
\hline 17 & $\mathrm{H}$ & $\mathrm{NH}_{2}$ & $\mathrm{H}$ & $\mathrm{C}_{14} \mathrm{H}_{12} \mathrm{~N}_{4}$ & 100 & 1.86 & 0 \\
\hline 18 & $\mathrm{H}$ & $\mathrm{NH}_{2}$ & $\mathrm{~F}$ & $\mathrm{C}_{14} \mathrm{H}_{11} \mathrm{FN}_{4}$ & 2.0 & 2.34 & 0 \\
\hline 19 & $\mathrm{H}$ & $\mathrm{NH}_{2}$ & $\mathrm{Cl}$ & $\mathrm{C}_{14} \mathrm{H}_{11} \mathrm{ClN}_{4}$ & 0.25 & 2.75 & 0 \\
\hline 20 & $\mathrm{H}$ & $\mathrm{NH}_{2}$ & $\mathrm{Br}$ & $\mathrm{C}_{14} \mathrm{H}_{11} \mathrm{BrN}_{4}$ & 0.1 & 3.06 & 0 \\
\hline 21 & $\mathrm{H}$ & $\mathrm{NH}_{2}$ & I & $\mathrm{C}_{14} \mathrm{H}_{11} \mathrm{IN}_{4}$ & 0.35 & 3.32 & 0 \\
\hline 22 & $\mathrm{H}$ & $\mathrm{NH}_{2}$ & $\mathrm{CF}_{3}$ & $\mathrm{C}_{15} \mathrm{H}_{11} \mathrm{~F}_{3} \mathrm{~N}_{4}$ & 3.3 & 3.07 & 0 \\
\hline 23 & $\mathrm{H}$ & $\mathrm{NO}_{2}$ & $\mathrm{H}$ & $\mathrm{C}_{14} \mathrm{H}_{10} \mathrm{~N}_{4} \mathrm{O}_{2}$ & $1.2 \times 10^{4}$ & 2.87 & 0 \\
\hline 24 & $\mathrm{H}$ & $\mathrm{NO}_{2}$ & F & $\mathrm{C}_{14} \mathrm{H}_{9} \mathrm{FN}_{4} \mathrm{O}_{2}$ & 6100 & 3.35 & 0 \\
\hline 25 & $\mathrm{H}$ & $\mathrm{NO}_{2}$ & $\mathrm{Cl}$ & $\mathrm{C}_{14} \mathrm{H}_{9} \mathrm{CIN}_{4} \mathrm{O}_{2}$ & 810 & 3.76 & 0 \\
\hline 26 & $\mathrm{H}$ & $\mathrm{NO}_{2}$ & $\mathrm{Br}$ & $\mathrm{C}_{14} \mathrm{H}_{9} \mathrm{BrN}_{4} \mathrm{O}_{2}$ & 1000 & 4.07 & 0 \\
\hline 27 & $\mathrm{H}$ & $\mathrm{NO}_{2}$ & I & $\mathrm{C}_{14} \mathrm{H}_{9} \mathrm{IN}_{4} \mathrm{O}_{2}$ & 540 & 4.33 & 0 \\
\hline 28 & $\mathrm{H}$ & $\mathrm{NO}_{2}$ & $\mathrm{CF}_{3}$ & $\mathrm{C}_{15} \mathrm{H}_{9} \mathrm{~F}_{3} \mathrm{~N}_{4} \mathrm{O}_{2}$ & $>10^{4}$ & 4.08 & 0 \\
\hline 29 & OMe & $\mathrm{OMe}$ & $\mathrm{H}$ & $\mathrm{C}_{16} \mathrm{H}_{15} \mathrm{~N}_{3} \mathrm{O}_{2}$ & 29 & 2.87 & 0 \\
\hline 30 & OMe & $\mathrm{OMe}$ & $\mathrm{F}$ & $\mathrm{C}_{16} \mathrm{H}_{14} \mathrm{FN}_{3} \mathrm{O}_{2}$ & 3.8 & 3.36 & 0 \\
\hline
\end{tabular}




\begin{tabular}{|c|c|c|c|c|c|c|c|}
\hline \multicolumn{8}{|c|}{ Continued } \\
\hline 31 & OMe & $\mathrm{OMe}$ & $\mathrm{Cl}$ & $\mathrm{C}_{16} \mathrm{H}_{14} \mathrm{ClN}_{3} \mathrm{O}_{2}$ & 0.31 & 3.77 & 0 \\
\hline 32 & OMe & $\mathrm{OMe}$ & $\mathrm{Br}$ & $\mathrm{C}_{16} \mathrm{H}_{14} \mathrm{BrN}_{3} \mathrm{O}_{2}$ & 0.025 & 4.08 & 0 \\
\hline 33 & OMe & $\mathrm{OMe}$ & I & $\mathrm{C}_{16} \mathrm{H}_{14} \mathrm{IN}_{3} \mathrm{O}_{2}$ & 0.89 & 4.34 & 0 \\
\hline 34 & OMe & OMe & $\mathrm{CF}_{3}$ & $\mathrm{C}_{17} \mathrm{H}_{14} \mathrm{~F}_{3} \mathrm{~N}_{3} \mathrm{O}_{2}$ & 0.24 & 4.08 & 0 \\
\hline 35 & NHMe & $\mathrm{H}$ & $\mathrm{Br}$ & $\mathrm{C}_{15} \mathrm{H}_{13} \mathrm{BrN}_{4}$ & 4 & 3.72 & 0 \\
\hline 36 & $\mathrm{NMe}_{2}$ & $\mathrm{H}$ & $\mathrm{Br}$ & $\mathrm{C}_{16} \mathrm{H}_{15} \mathrm{BrN}_{4}$ & 84 & 4.45 & 0 \\
\hline 37 & $\mathrm{NHCO}_{2} \mathrm{Me}$ & $\mathrm{H}$ & $\mathrm{Br}$ & $\mathrm{C}_{16} \mathrm{H}_{13} \mathrm{BrN}_{4} \mathrm{O}_{2}$ & 12 & 3.89 & 0 \\
\hline 38 & $\mathrm{H}$ & $\mathrm{OH}$ & $\mathrm{Br}$ & $\mathrm{C}_{14} \mathrm{H}_{10} \mathrm{BrN}_{3} \mathrm{O}$ & 4.7 & 3.61 & 0 \\
\hline 39 & $\mathrm{H}$ & NHAc & $\mathrm{Br}$ & $\mathrm{C}_{16} \mathrm{H}_{13} \mathrm{BrN}_{4} \mathrm{O}$ & 40 & 3.21 & 0 \\
\hline 40 & $\mathrm{H}$ & NHMe & $\mathrm{Br}$ & $\mathrm{C}_{15} \mathrm{H}_{13} \mathrm{BrN}_{4}$ & 7.0 & 3.72 & 0 \\
\hline 41 & $\mathrm{H}$ & NHEt & $\mathrm{Br}$ & $\mathrm{C}_{16} \mathrm{H}_{15} \mathrm{BrN}_{4}$ & 12 & 4.25 & 0 \\
\hline 42 & $\mathrm{H}$ & $\mathrm{NMe}_{2}$ & $\mathrm{Br}$ & $\mathrm{C}_{16} \mathrm{H}_{15} \mathrm{BrN}_{4}$ & 11 & 4.45 & 0 \\
\hline 43 & $\mathrm{NH}_{2}$ & $\mathrm{NH}_{2}$ & $\mathrm{Br}$ & $\mathrm{C}_{14} \mathrm{H}_{12} \mathrm{BrN}_{5}$ & 0.12 & 2.18 & 0 \\
\hline 44 & $\mathrm{NH}_{2}$ & NHMe & $\mathrm{Br}$ & $\mathrm{C}_{15} \mathrm{H}_{14} \mathrm{BrN}_{5}$ & 0.69 & 2.77 & 0 \\
\hline 45 & $\mathrm{NH}_{2}$ & $\mathrm{NMe}_{2}$ & $\mathrm{Br}$ & $\mathrm{C}_{16} \mathrm{H}_{16} \mathrm{BrN}_{5}$ & 159 & 3.23 & 0 \\
\hline 46 & $\mathrm{NH}_{2}$ & OMe & $\mathrm{Br}$ & $\mathrm{C}_{15} \mathrm{H}_{13} \mathrm{BrN}_{4} \mathrm{O}$ & 3.8 & 3.22 & 0 \\
\hline 47 & $\mathrm{NH}_{2}$ & $\mathrm{Cl}$ & $\mathrm{Br}$ & $\mathrm{C}_{14} \mathrm{H}_{10} \mathrm{BrClN}_{4}$ & 6.5 & 3.82 & 0 \\
\hline 48 & $\mathrm{NO}_{2}$ & $\mathrm{NH}_{2}$ & $\mathrm{Br}$ & $\mathrm{C}_{14} \mathrm{H}_{10} \mathrm{BrN}_{5} \mathrm{O}_{2}$ & 53 & 3.96 & 0 \\
\hline 49 & $\mathrm{NO}_{2}$ & NHMe & $\mathrm{Br}$ & $\mathrm{C}_{15} \mathrm{H}_{12} \mathrm{BrN}_{5} \mathrm{O}_{2}$ & 68 & 4.31 & 0 \\
\hline 50 & $\mathrm{NO}_{2}$ & $\mathrm{NMe}_{2}$ & $\mathrm{Br}$ & $\mathrm{C}_{16} \mathrm{H}_{14} \mathrm{BrN}_{5} \mathrm{O}_{2}$ & 2000 & 4.24 & 0 \\
\hline 51 & $\mathrm{NO}_{2}$ & NHAc & $\mathrm{Br}$ & $\mathrm{C}_{16} \mathrm{H}_{12} \mathrm{BrN}_{5} \mathrm{O}_{3}$ & 28 & 3.13 & 0 \\
\hline 52 & $\mathrm{NO}_{2}$ & $\mathrm{OMe}$ & $\mathrm{Br}$ & $\mathrm{C}_{15} \mathrm{H}_{11} \mathrm{BrN}_{4} \mathrm{O}_{3}$ & 15 & 3.86 & 0 \\
\hline 53 & $\mathrm{NO}_{2}$ & $\mathrm{Cl}$ & $\mathrm{Br}$ & $\mathrm{C}_{14} \mathrm{H}_{8} \mathrm{BrClN}_{4} \mathrm{O}_{2}$ & 25 & 4.25 & 0 \\
\hline 54 & $\mathrm{OCH}_{2} \mathrm{O}$ & & $\mathrm{Br}$ & $\mathrm{C}_{15} \mathrm{H}_{10} \mathrm{BrN}_{3} \mathrm{O}_{2}$ & 15 & 4.21 & 0 \\
\hline 55 & $\mathrm{OH}$ & $\mathrm{OH}$ & $\mathrm{Br}$ & $\mathrm{C}_{14} \mathrm{H}_{10} \mathrm{BrN}_{3} \mathrm{O}_{2}$ & 0.17 & 3.01 & 0 \\
\hline $56^{* \#}$ & OEt & OEt & $\mathrm{Br}$ & $\mathrm{C}_{18} \mathrm{H}_{18} \mathrm{BrN}_{3} \mathrm{O}_{2}$ & 0.006 & 5.14 & 1 \\
\hline $57^{*}$ & $\mathrm{OPr}$ & OPr & $\mathrm{Br}$ & $\mathrm{C}_{20} \mathrm{H}_{22} \mathrm{BrN}_{3} \mathrm{O}_{2}$ & 0.17 & 6.21 & 1 \\
\hline $58^{*}$ & $\mathrm{OBu}$ & $\mathrm{OBu}$ & $\mathrm{Br}$ & $\mathrm{C}_{22} \mathrm{H}_{26} \mathrm{BrN}_{3} \mathrm{O}_{2}$ & 105 & 7.27 & 1 \\
\hline 59 & 5,6di-OME & & & $\mathrm{C}_{16} \mathrm{H}_{14} \mathrm{~B}_{\mathrm{r}} \mathrm{N}_{3} \mathrm{O}_{2}$ & 1367 & 4.08 & 0 \\
\hline 60 & 7,8di-OME & & & $\mathrm{C}_{16} \mathrm{H}_{14} \mathrm{~B}_{\mathrm{r}} \mathrm{N}_{3} \mathrm{O}_{2}$ & $>10^{4}$ & 4.08 & 0 \\
\hline 61 & 2-Me & & 3'-Br & $\mathrm{C}_{17} \mathrm{H}_{16} \mathrm{~B}_{\mathrm{r}} \mathrm{N}_{3} \mathrm{O}_{2}$ & $>10^{4}$ & 2.94 & 0 \\
\hline 62 & $2-\mathrm{NH}_{2}$ & & 3'-Br & $\mathrm{C}_{16} \mathrm{H}_{15} \mathrm{BrN}_{4} \mathrm{O}_{2}$ & 463 & 4.03 & 0 \\
\hline 63 & 4N-Me & & 3’-Br & $\mathrm{C}_{17} \mathrm{H}_{16} \mathrm{BrN}_{3} \mathrm{O}_{2}$ & 152 & 4.01 & 0 \\
\hline 64 & 5-OMe & & 3'-Br & $\mathrm{C}_{17} \mathrm{H}_{16} \mathrm{BrN}_{3} \mathrm{O}_{3}$ & 0.67 & 3.78 & 0 \\
\hline 65 & 8-OMe & & 3'-Br & $\mathrm{C}_{17} \mathrm{H}_{16} \mathrm{BrN}_{3} \mathrm{O}_{3}$ & $>10^{4}$ & 3.78 & 0 \\
\hline 66 & $\mathrm{H}$ & & $2^{\prime}-\mathrm{Br}$ & $\mathrm{C}_{16} \mathrm{H}_{14} \mathrm{BrN}_{3} \mathrm{O}_{2}$ & 128 & 3.56 & 0 \\
\hline 67 & $\mathrm{H}$ & & $4^{\prime}-\mathrm{Br}$ & $\mathrm{C}_{16} \mathrm{H}_{14} \mathrm{BrN}_{3} \mathrm{O}_{2}$ & 0.96 & 4.04 & 0 \\
\hline $68^{*}$ & $\mathrm{H}$ & & 3',4'-diBr & $\mathrm{C}_{16} \mathrm{H}_{13} \mathrm{Br}_{2} \mathrm{~N}_{3} \mathrm{O}_{2}$ & 0.072 & 5.11 & 1 \\
\hline $69^{*}$ & $\mathrm{H}$ & & 3',5'-diBr & $\mathrm{C}_{16} \mathrm{H}_{13} \mathrm{Br}_{2} \mathrm{~N}_{3} \mathrm{O}_{2}$ & 113 & 5.24 & 1 \\
\hline
\end{tabular}

${ }^{*} \log P>5$ is a violation in the Lipinski's rule of five. ${ }^{*}$ Molecule with the highest biological activity, represented by the lower $I C_{50}$ 


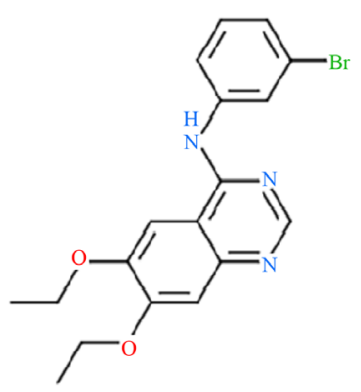

Molecular formula: $\mathrm{C}_{18} \mathrm{H}_{18} \mathrm{BrN}_{3} \mathrm{O}_{2}$

Molecular weight: 387.06

Number of HBA: 4

Number of HBD: 1

Mol LogP: 5.08 (>5)

MolLogS: $-6.01($ inLog $($ moles/L $)) 0.38($ in $\mathrm{mg} / \mathrm{L})$

MoIPSA: $43.74 \mathrm{~A}^{2}$

MolVol: $323.31 \mathrm{~A}^{3}$

Number of stereo centers: 0

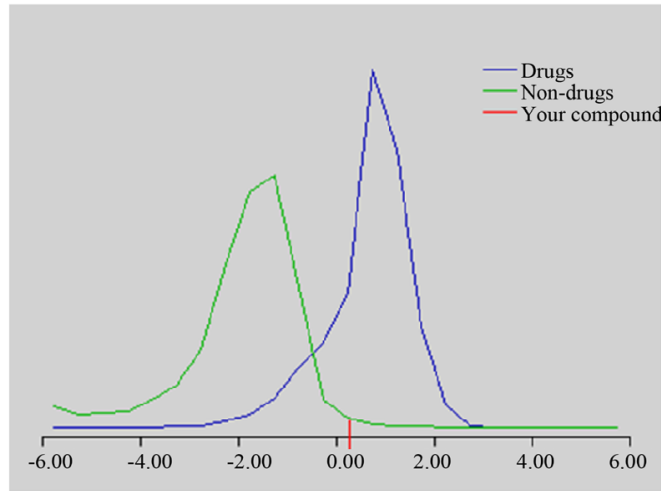

Figure 1. Compound 56 is expected to have poor pharmacokinetics parameters: $\log P>5$ and low drug-likeness score.

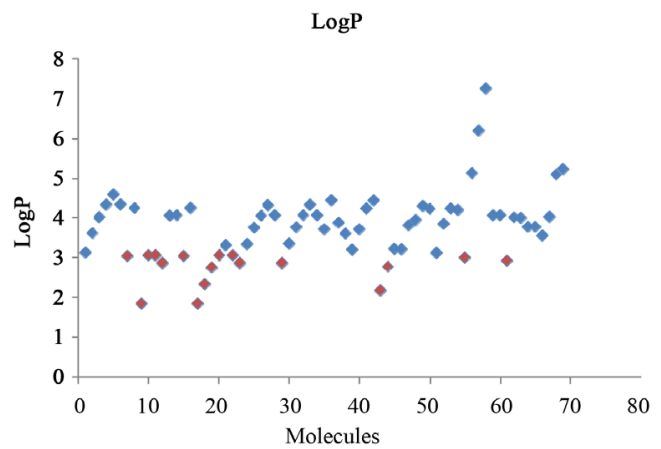

(a)

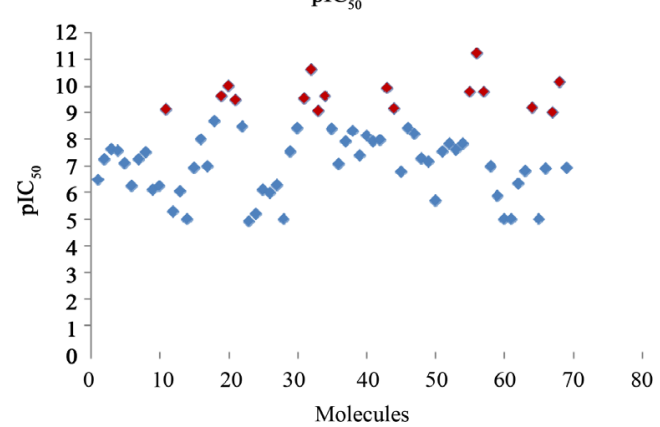

(b)

Figure 2. Selection of molecules according to $\log P$ and $p I C_{50}$ parameters. In (a), red compounds $9,7,10,11,12,15,17,18,19,20,22$, 23, 29, 43, 44, 55, 61 have $\log P$ values between 2 and 3 (an optimal range). In (b), red compounds $11,19,20,21,31,32,33,34,43,44$, $55,56,57,64,67,68$ have optimal pIC $_{50}$ above 9.0 . 
may have a high correlation between biological activity and lipophilicity. This is appropriate for the construction of a parabolic bilinear model.

The dataset in this study presents molecules with $p I C_{50}$ higher than $9.0\left(I C_{50}\right.$ lower than $1 \mathrm{nM}$ and, therefore, highly active [30]), which are selected and colored in red Figure 2(a). Among these compounds, some can be identified as potentially having favorable pharmacokinetics properties by calculating the corresponding $\log P$. Kubinyi [4] have demonstrated an ideal range in $\log P$ for selecting molecules, which was used to select some quinazolines in this study; molecules with calculated $\log P$ values between 2.0 and 3.0 were selected, as shown in red Figure 2(b). These authors have also demonstrated that a bilinear model describes a correlation between bioactivity and lipophilicity of a series of similar molecules. This model indicates that there is optimal lipophilicity, which can reflect pharmacokinetic and pharmacodynamic requirements ideals, which increase or decrease can lead to progressive reduction of the biological activity. Based on this study, a similar model was built to correlate the biological activity data and $\log P$ for the series of quinazoline EGFR inhibitors

\subsection{Selection of Molecules that Showed Better Results of Pharmacokinetics Parameters Based on $\log P$ and $p I C_{50}$ Obtained by the Bilinear Model}

Figure 3 shows the variation of $\log P$ as a function of the biological activity $\left(p I C_{50}\right)$. According to the bilinear parabolic correlation, six molecules have been identified as having the best profile by considering both biological activity and lipophilicity. Consequently, molecules 11, 19, 20, 43, 44 and 55 can be considered the best candidates obtained in our studies. This result excludes the molecule $\mathbf{5 6}$.

According to the proposed model, six molecules of Table 1, which are colored in red in the Figure 3 (11, 19, 20, 43, 44, 55) showed the best profile when analyzing the ideal values for both $\log P$ and bioactivity. This result indicates that such molecules have high bioactivity and are probably favorable pharmacodynamic and pharmacokinetically. Thus, the previously proposed compound $\mathbf{5 6}$ does not match ideal requirements to be the best drug candidate from that pool of quinazoline EGFR inhibitors. In addition, there is no scientific evidence that the compound 56 has good in vivo pharmacokinetics parameters. Probably, the nonpolar $O$-ethyl and propyl groups in molecules $\mathbf{5 6}$ and $\mathbf{5 7}$ contribute to increase the inhibition of the receptor. However, these groups are responsible for increasing the $\log P$ value, thus possibly causing reduction in bioavailability. Thus, incorporation of polar moieties, e.g. as terminal groups at the $O$-ethyl and propyl chains, could be attempt to improve the bioavailability without loosing the interaction with the receptor.

\subsection{Molecules 11, 19, 20, 43, 44, 55 with Favorable Pharmacokinetic Property and Molecule 56 Will Probably Not Show Good Oral Bioavailability}

Figure 4 shows the pharmacokinetics results for the compounds proposed as EGFR inhibitors.

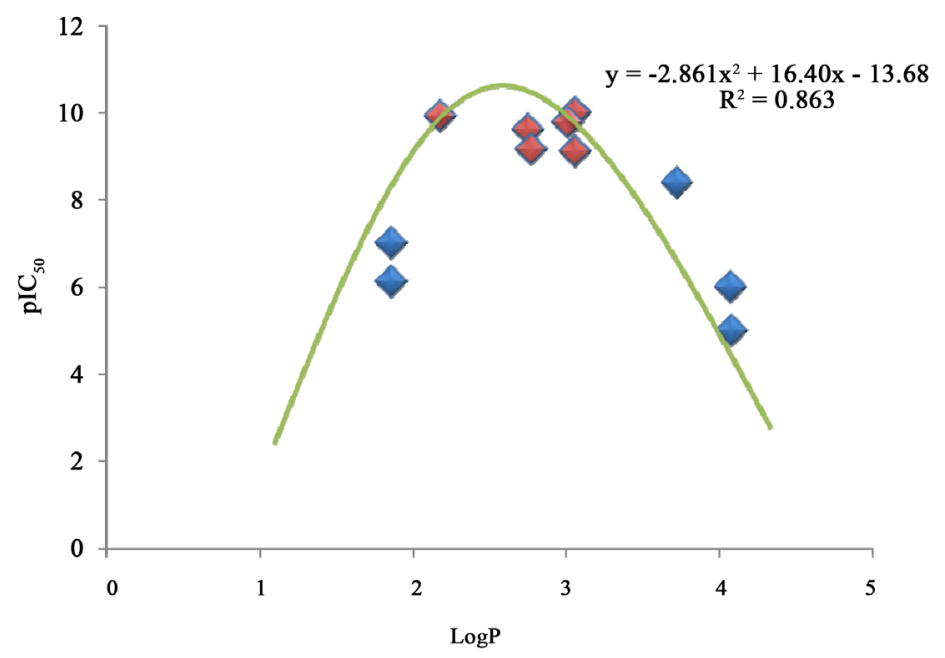

Figure 3. Bilinear Model between lipophilicity and biological activity. Compounds in red $(11,19,20,43,44,55)$ show optimal $p I C_{50}$ and $\log P$, as obtained from the correlation between lipophilicity and biological activity. 
<smiles></smiles>

Figure 4. Compounds 11, 19, 20, 43, 44, 55 with favorable pharmacokinetics properties and molecule 56, which will probably not have good oral bioavailability.

The result of this study confirms the necessity of previous computational modeling to select the most promising drug candidates. A potent inhibitor, which has poor absorption and, hence, low oral bioavailability, may not be easily accepted by the patients. So, it can be discarded by the pharmaceutical industry even at later stages of drug development.

\section{Experimental Analysis}

\section{In Silico Study of the Pharmacokinetics Parameters of Quinazolines}

The inhibition capacity of 69 quinazolines for EGFR [11] has been previously evaluated elsewhere using $I C_{50}$ assays. The authors have conducted a search in the literature for the group of molecules [11] and it was not found studies using these compounds. In the present study, the $\log P$ for all 69 molecules were calculated using the ChemSketch program (www.acdlabs.com) [31] Subsequently, the molecules were designed and saved in CS ChemDraw files (*.cdx), converted into SMILES and submitted to calculations using the freely available Molinspiration program [6]. Molinspiration offers a broad range of cheminformatics tools supporting molecule manipulation and processing, normalization of molecules, generation of tautomers, molecule fragmentation, calculations of various molecular properties useful in QSAR, molecular modelling and drug design, high quality molecule depiction, molecular database tools supporting substructure and similarity searches. These tools are important for the calculation of important molecular properties $(\log P$, polar surface area, number of hydrogen bond donors and acceptors and others), as well as for the prediction of bioactivity score for the most important drug targets (such as G protein-coupled receptor-GPCR ligands and kinase inhibitors) [6]. The cheminformatics Molinspiration platform [6] also permits to evaluate if a given molecule violated any Lipinski's rule of five [5]. Molecules that do not violate the rule can be considered to have success in pharmacokinetics tests, such as oral bioavailability. The ICM-molsoft platform [7] was also used to analyze the molecules. Molsoft [7] develops new technology and proprietary algorithms for molecular modeling with applications to protein and small molecule structure prediction, docking and structure based drug design; molecular visualization and animation, bioinformatics, cheminformatics, and laboratory information management systems. Furthermore, Molsoft [7] has Free Online Servers as Drug Likeness prediction. All molecular property predictors are calculated using fragment-based contributions. Molsoft [7] developed an original method for splitting a molecule into a set of linear or non-linear fragments of different length and representation levels and counting the number of occurrences of 
each chemical pattern found.

\section{Conclusion}

It has been shown that a highly potent EGFR inhibitor should not be the most pharmacokinetically favorable agent, therefore it can be advantageous to choose a less potent, but more orally bioavailable candidate to further studies. So, the rational design of new drugs provides useful tools for synthesis of promising drug candidates, thus saving time and costs during drug development.

\section{Acknowledgements}

The authors are thankful to Program to Support Publishing (PROPESQ) of Federal University of Juiz de ForaUFJF and FAPEMIG.

\section{Conflict of Interest}

There is not conflict of interest in this paper.

\section{References}

[1] Thomas, G. (2012) Química Medicinal: uma introdução. Guanabara Koogan, São Paulo.

[2] Barreiro, E.J. (2008) As Bases Moleculares da Ação dos Fármacos. 2th Edition, C.A.M, Porto Alegre.

[3] Fraga, C.A.M. and Barreiro, E.J. (1996) Cardiotônicos: histórico e perspectivas de uma importante classe de agentes terapêuticos. Quimica Nova, 19, 182-189.

[4] Kubinyi, H. (1977) Quantitative Structure-Activity Relations. 7. The Bilinear Model, a New Model for Nonlinear Dependence of Biological Activity on Hydrophobic Character. Journal of Medicinal Chemistry, 20, 625-629. http://dx.doi.org/10.1021/jm00215a002

[5] Lombardo, F., Lipinski, C.A., Dominy, B.W. and Feeney, P.J. (1997) Experimental and Computational Approaches to Estimate Solubility and Permeability in Drug Discovery and Development Setting. Advanced Drug Delivery Reviews, 23, 3-25. http://dx.doi.org/10.1016/S0169-409X(96)00423-1

[6] http://www.molinspiration.com

[7] http://www.molsoft.com/servers.html

[8] Connolly, D.J., Cusack, D., O’Sullivan, T.P. and Guiry, P.J. (2005) Synthesis of Quinazolinones and Quinazolines. Tetrahedron, 61, 10153-10202. http://dx.doi.org/10.1016/j.tet.2005.07.010

[9] Katritzky, A.R. and Pozharskii, A.F. (2003) Handbook of Heterocyclic Chemistry. Pergamon Press, Oxford.

[10] Mhaske, S.B. and Argade, N.P. (2006) The Chemistry of Recently Isolated Naturally Occurring Quinazolinone Alkaloids. Tetrahedron, 62, 9787-9826. http://dx.doi.org/10.1016/j.tet.2006.07.098

[11] Bridges, A.J., Zhou, H., Cody, D.R., Rewcastle, G.W., McMichael, A., Showalter, H.D., Fry, D.W., Kraker, A.J. and Denny, W.A.T. (1996) Tyrosine Kinase Inhibitors. 8. An Unusually Steep Structure-Activity Relationship for Analogues of 4-(3-Bromoanilino)-6,7-dimethoxyquinazoline (PD 153035), a Potent Inhibitor of the Epidermal Growth Factor Receptor. Journal of Medicinal Chemistry, 39, 267-276. http://dx.doi.org/10.1021/jm9503613

[12] Rahman, M.U., Rathore, A., Siddiqui, A.A., Parveen, G. and Yar, M.S. (2014) Synthesis and Characterization of Quinazoline Derivatives: Search for Hybrid Molecule as Diuretic and Antihypertensive Agents. Journal of Enzyme Inhibition and Medicinal Chemistry, 29, 733-743. http://dx.doi.org/10.3109/14756366.2013.845820

[13] Matsuda, H., Yoshikawa, M., Ko, S., Iinuma, M. and Kubo, M. (1998) Antinociceptive and Anti-Inflammatory Activities of Evodiamine and Rutaecarpine. Nature Medicine, 52, 203-208.

[14] Buchanan, J.G. and Sable, H.Z. (1972) Selective Organic Transformations. Wiley-Interscience, New York.

[15] Hibino, S. and Choshi, T. (2001) Simple Indole Alkaloids and Those with a Nonrearranged Monoterpenoid Unit. Natural Product Reports, 18, 66-87. http://dx.doi.org/10.1039/b004055j

[16] Koepfly, J.B., Mead, J.F. and Brockman Jr., J.A. (1947) An Alkaloid with High Antimalarial Activity from Dichroa febrifuga. Journal of the American Chemical Society, 69, 1837-1837. http://dx.doi.org/10.1021/ja01199a513

[17] Kacker, I.K. and Zaheer, S.H. (1951) Synthesis of Substituted 4-Quinazolones. Journal of Indian Chemical Society, 28, 344-346.

[18] Amin, A.H., Mehta, D.R. and Samarth, S.S. (1970) Biological Activity in the Quinazolone Series. Progress in Drug 
Research, 14, 218-268. http://dx.doi.org/10.1007/978-3-0348-7075-7_5

[19] Fry, D.W., Kraker, A.J., McMichael, A., Ambroso, L.A., Nelson, J.M., Leopold, W.R., Connors, R.W. and Bridges, A.J. (1994) A Specific Inhibitor of the Epidermal Growth Factor Receptor Tyrosine Kinase. Science, 265, 1093-1095. http://dx.doi.org/10.1126/science.8066447

[20] Baselga, J. (2006) Targeting Tyrosine Kinases in Cancer: The Second Wave. Science, 312, 1175-1178. http://dx.doi.org/10.1126/science.1125951

[21] Rewcastle, G.W., Denny, W.A., Bridges, A.J., Zhou, H., Cody, D.R., McMichael, A. and Fry, D.W. (1995) Tyrosine Kinase Inhibitors. Synthesis and Structure-Activity Relationships for 4-[(Phenylmethyl)amino] and 4-(Phenylamino) Quinazolines as Potent Adenosine 5'-Triphosphate Binding Site Inhibitors of the Tyrosine Kinase Domain of the Epidermal Growth Factor Receptor. Journal of Medicinal Chemistry, 38, 3482-3487. http://dx.doi.org/10.1021/jm00018a008

[22] Levitzki, A. (2003) Protein Kinase Inhibitors as a Therapeutic Modality. Accounts of Chemical Research, 36, $462-469$. http://dx.doi.org/10.1021/ar0201207

[23] Vansteenkiste, J.F. (2004) Gefitinib (Iressa): A Novel Treatment for Non-Small Cell Lung Cancer. Expert Review of Anticancer Therapy, 4, 5-17. http://dx.doi.org/10.1586/14737140.4.1.5

[24] Bonomi, P. (2003) Erlotinib: A New Therapeutic Approach for Non-Small Cell Lung Cancer. Expert Opinion on Investigational Drugs, 12, 1395-1401. http://dx.doi.org/10.1517/13543784.12.8.1395

[25] Gilmer, T.M., Cable, L., Alligood, K., Rusnak, D., Spehar, G., Gallagher, K.T., Woldu, E., Carter, H.L., Truesdale, A.T., Shewchuk, L. and Wood, E.R. (2008) Impact of Common Epidermal Growth Factor Receptor and HER2 Variants on Receptor Activity and Inhibition by Lapatinib Wood. Cancer Research, 68, 571-579. http://dx.doi.org/10.1158/0008-5472.CAN-07-2404

[26] Traxler, P. (2003) Tyrosine Kinases as Targets in Ancer Therapy-Successes and Failures. Expert Opinion on Therapeutic Targets, 7, 215-234. http://dx.doi.org/10.1517/14728222.7.2.215

[27] Vema, A., Panigrahi, S.K., Rambabu, G., Gopalakrishinan, B., Sarma, J.A.R.P. and Desiraju, G.R. (2003) Design of EGFR Kinase Inhibitors: A Ligand Based Approach and Its Confirmation with Structure Based Studies. Bioorganic \& Medicinal Chemistry, 11, 4643-4653. http://dx.doi.org/10.1016/s0968-0896(03)00482-6

[28] Golan, D.E. (2009) Principles of Pharmacology. 2nd Edition, Medicine \& Health Science Books, New York.

[29] Howland, R.D. and Mycek, M.J. (2008) Farmacologia Ilustrada. 3rd Edition, Artmed, São Paulo.

[30] García-Echeverría, C., Traxler, P. and Evans, D.B. (2000) ATP Site-Directed Competitive and Irreversible Inhibitors of Protein Kinases. Medicinal Research Reviews, 20, 28-57. http://dx.doi.org/10.1002/(SICI)1098-1128(200001)20:1<28::AID-MED2>3.0.CO;2-2

[31] ACD/Labs Release 2012 (File Version 14.01, Build 65894), 17 Sep. 2013. www.acdlabs.com 